\title{
Årsberetning 1976-1977
}

I 1976 holdtes Grundtvig-Selskabets årsmøde på Aarhus Universitet den 2.-3. december. Det reviderede regnskab forelagdes af selskabets sekretær. Til ny kasserer valgtes stud. theol. Erik Krebs Jensen, der dog i år har måttet træde tilbage p. gr. af sygdom. Regnskabet er derefter gået tilbage til sekretæren. Som revisor fungerer Johs. F. B. Eriksen.

Derefter talte professor Gustav Albeck om Grundtvig som dagbogsskribent. Foredraget er trykt i Grundtvig-Studier 1976. M. A. Edward Broadbridge havde kaldt sit foredrag „En englænders møde med Grundtvigs tanker“. I foredraget indgik prøver på talerens oversættelse af Grundtvig-tekster. Om aftenen indledte cand. mag. Bodil Pagter en samtale om prof. dr. Erica Simons højskole Crau du Sapt, syd for Lyon. I samtalen indgik oplysninger fra flere medlemmer af selskabet, der ligeledes havde besøgt højskolen og deltaget $i$ et kursus dér. Næste formiddag redegjorde dr. Kaj Thaning for sit foredrag om Grundtvigs højskoletanker på universitetet i Bari (efter indbydelse af prof. Santomauro) og sin derpå følgende rejse til de i Apulien oprettede kulturcentrer (CSEP) for voksenundervisning. Rejsen gav anledning til en indbydelse til italienske lærere $\mathrm{i}$ voksenundervisning til et besøg i Danmark, som fandt sted på Båring højskole i foråret 1977.

Arbejdet med udgivelsen af Grundtvigs dagbøger er nu tilendebragt og trykningen overladt til Det danske Sprog- og Litteraturselskab. Den engelske oversættelse af et Grundtvig-udvalg fortsætter under arbejdsudvalgets tilsyn med lektor Niels Lyhne Jensen som særlig sagkyndig. Endvidere er det under overvejelse at udgive et udvalg af Grundtvig-salmer til tysk, foretaget af fhv. sognepræst Andreas Øster.

Efter indbydelse fra Oehlenschläger-Selskabet har GrundtvigSelskabets formand og sekretær deltaget i et møde med repræsentanter for andre litterære selskaber om eventuelt samarbejde. Det besluttedes, at en årlig publikation skulle tilgå selskabernes medlemmer med oplysning om de enkelte selskabers formål, adresser 
og planer for arrangementer. Grundtvig-Selskabet har meddelt de ønskede oplysninger; men den påtænkte publikation har endnu ikke set dagens lys. - Efter indbydelse af Det kgl. danske Videnskabernes Selskab har redaktørerne af Grundtvig-Studier deltaget i et orienterende møde med andre videnskabelige selskaber om eventuelt samarbejde mht. lokaler, priser herfor o. lign.

Det udvidede omfang af Grundtvig-Studier 1977 skyldes, at hovedindholdet er bidragene til Grundtvig-seminaret på Sandbjerg i 1975 i revideret og udvidet form. Til særskilt trykning heraf har selskabets næstformand modtaget en bevilling af Statens humanistiske Forskningsråd. Til Grundtvig-Studier 1979 foreligger allerede nu stof.

Kontoret i Vartov oplyser, at selskabet nu har 423 medlemmer, heraf de 377 i Danmark (herunder 38 studerende) 13 i Sverige, 11 i USA, 6 i Norge, 5 i Tyskland (Forbundsrepublikken), 2 i England samt 1 i hvert af de følgende lande: Finland, Irland, Holland, Frankrig, Schweiz, Østrig og Japan.

William Michelsen.

\section{Meddelelse fra redaktionen}

At dette 30.-31. bind af Grundtvig-Studier fremtræder som en dobbelt årgang af Grundtvig-Selskabets årsskrift, skyldes ønsket om inden for Grundtvig-Studiers sædvanlige ramme at give plads for et moderne forskningsprojekt, der behandler Grundtvigs salmer og prædikener.

Da omfanget denne gang er 3 gange det normale, vil medlemmerne forstå, at kontingentet denne gang må gælde 2 år. Der er ved fremsendelsen af nærværende dobbeltbind for 1977-78 vedlagt et girokort for indbetaling af kontingentet for 1977. Kontingentet er $40 \mathrm{kr}$., for studerende $30 \mathrm{kr}$. Kontingentet for 1978 vil blive opkrævet samtidig med indkaldelsen til årsmødet i 1978.

Næste årgang vil udkomme i 1979. 